Nama : Trisuci Rahmadhani

Nim : :101001190061

Jurusan : Hukum Keluarga Islam (B)

\title{
TUGAS PENGGANTI UTS
}

1. Menurut saudara, apakah langkah tim kuasa hukum Andi Suhaimi Dalimunthe-Faizal Amri siregar sudah tepat dengan menggugat hasil pemelihan umum/pemilihan kepala daerah ke PTUN ? Jelaskan disertai dengan referensi.

Jawaban :

Menurut saya, Menurut saya, berdasarkan soal langkah tim kuasa hukum Andi Suhaimi Dalimunthe - Faizal Amri Siregar tidak tepat dalam menggugat hasil pemilihan umum/pemilihan kepala daerah ke PTUN, karena sengketa hasil pemilu secara khusus menjadi kompetensi Mahkamah Konstitusi sebagaimana diatur dalam Pasal 24C ayat (1) UUD 1945 menegaskan bahwa: MK berwenang mengadili pada tingkat pertama dan terakhir yang putusannya terhadap Undang-Undang Dasar, memutus sengketa kewenangan lembaga negara yang kewenangannya diberikan oleh Undang-Undang Dasar, memutus pembubaran partai politik, dan memutus perselisihan tentang hasil pemilihan umum. kemudian diperkuat dalam Pasal 263C Undang-Undang Nomor 12 Tahun 2008 tentang Perubahan atas Undang-Undang Nomor 32 Tahun 2004 tentang Pemerintahan Daerah. Pasal 263 C yang menyatakan bahwa: Penanganan sengketa hasil penghitungan suara pemilihan kepala daerah dan wakil kepala daerah oleh Mahkamah Agung dialihkan kepada Mahkamah Konstitusi paling lama 18 (delapan belas) bulan sejak Undang-Undang ini diundangkan. Dengan demikian, kewenangan MK yang semula hanya memutus perselisihan hasil pemilihan umum Presiden, DPR, DPRD, dan DPD menjadi bertambah dengan memutus perselisihan hasil pemilukada. Pasca keluarnya putusan MK No. 97/PUU-XI/2013, kewenangan MK dicabut dalam memutus sengketa hasil Pilkada dan menjadi terbatas hanya pada memutus perselisihan hasil pemilihan umum legislatif dan pemilu presiden dan wakil presiden. Namun selama belum ada UU yang mengatur, MK masih berwenang memutus sengketa hasil Pilkada.

Namun di artikel ini, Yusril yang merupakan kuasa hukum pasangan Andi Suhaimi Dalimunthe - Faizal Amri Siregar mengajukan gugatan ke PTUN buka tentang hasil pemilihan umum/pemilihan kepala daerah, melainkan keputusan yang dikeluarkan oleh KPU Labuhanbatu selaku pejabat tata usaha negara tentang paslon pemenang. Keputusan tentang penetapan paslon pemenang bukanlah berkaitan dengan hasil penghitungan suara yang jika terjadi sengketa menjadi kewenangan Mahkamah Konstitusi untuk mengadilinya. Keputusan untuk menentukan hak calon pemenang murni merupakan keputusan KPU sebagai penyelenggara atau badan administrasi negara, yang merupakan keputusan pengadilan TUN. 


\section{Referensi :}

1. Inosentius Samsul. 2014. "Sengketa pemilihan kepala daerah pasca keputusan MK: Kewenangan siapa ?"._Info Singkat Hukum_P3DI 6(10) Info Singkat-VI-10-II-P3DIApril-2014-6.pdf

2. https://ihza-ihza.com/tag/keputusan/

2. Jika gugatan diajukan, apa yang menjadi objek sengketanya? Jelaskan

Jawaban :

Sengketa yang diajukan tim kuasa hukum Andi Suhaimi Dalimunthe-Faizal Amri siregar ke Mahkamah Konstitusi terkait dugaan praktik kecurangan dan/atau pelanggaran yang merugikan perolehan suara Pemohon secara signifikan dan menguntungkan perolehan suara Pasangan Calon lain. Dengan memperlihatkan bukti-bukti kecurangan di 7 TPS dari 9 TPS yang telah diperintahkan sebelumnya oleh Mahkamah Konstitusi untuk dilaksanakan Pemungutan Suara Ulang (PSU).

Adapun berdasarkan artikel, objek sengketa pada kasus tersebut adalah keputusan yang dikeluarkan oleh KPU Labuhanbatu selaku pejabat tata usaha negara tentang paslon pemenang, yang dimana keputusan tersebut dikeluarkan sebelum adanya putusan MK. Karena telah terjadi sengketa yang dimana terkait dugaan praktik kecurangan dan/atau pelanggaran yang merugikan perolehan suara pemohon secara signifikan dan menguntungkan perolehan suara pasangan calon lain dalam hal ini permohonan perselisihan sudah didaftarkan di Mahkamah Konstitusi, maka KPU harus menunggu putusan MK baru menetapkan paslon pemenang.

Menetapkan paslon pemenang bisa jadi masalah karena hasil PSU didaftarkan menjadi perselisihan di Mahkamah Konstitus dan Ini merupakan kebijakan yang keliru yang tidak memperhatikan prinsip kehati-hatian dan kepastian hukum dalam asas-asas umum pemerintahan yang baik. Dengan alasan inilah kemungkinan penggugat ingin menggugat badan atau pejabat TUN yang telah mengeluarkan keputusan penetapan Paslon pemenang ke Pengadilan TUN. 